\title{
An Application of Heterotransplantation of a Human Glioma Cell Line to Hereditary Asplenic-athymic (Lasat) Mice
}

\author{
Masafumi Yamashita, Iwao Takeshita, Michiya OHta*, \\ Tosuke TAKaKı and Katsutoshi KITAMURA \\ Department of Neurosurgery, Neurological Institute, Faculty \\ of Medicine, Kyushu University, Fukuoka 812 \\ * Department of Neuropathology, Neurological Institute, Faculty \\ of Medicine, Kyushu University
}

\begin{abstract}
Summary
Hereditary asplenic-athymic (lasat) mice were used in a study of heterotransplantation of an established human glioma cell line designated KNS-42 derived from a glioblastoma located in the right posterior frontal and parietal lobes of a 16-year-old boy. All six lasat mice, inoculated with $6 \times 10^{6}$ to $1 \times 10^{7}$ cells subcutaneously, developed permanently growing tumors which were strikingly similar to the parent tumor. In paraffin sections the transplanted tumor tissue was of high cellularity and showed perivascular arrangement of tumor cells with marked endothelial proliferation, mitotic figures, and small necrotic foci. Invasive proliferation of the tumor cells beyond the proper connective tissue capsule of the mouse was also noted. Under electron microscopy tumor cells in the mice, similar to the cell line, retained a large amount of glial filaments measuring $9-10 \mathrm{~nm}$ in diameter. In an immunodiffusion study, the cell line and the tumors in mice showed a precipitation line with rabbit immune serum against purified glial fibrillary acidic protein.
\end{abstract}

Key words: Hereditary asplenic-athymic mouse, human glioma, heterotransplantation

\section{Introduction}

Heterotransplantation of many human malignant tumors into athymic nude mouse is usually followed by development of tumors, which are successfully passaged serially, retaining their morphological and biochemical characteristics. ${ }^{10,12,24,27,29,30,31)}$ Application of this mutant mouse should permit further experimental studies on human malignancy. For this reason, it is extremely important to establish cell lines ${ }^{9,14)}$ from human malignant tumors that are transplantable into athymic nude mice.

A number of human gliomas and cell lines derived from human gliomas have been studied in an attempt to produce tumors in athymic nude mouse, ${ }^{2,9,14,20,22,23,26,29,33)}$ but only a few papers presenting both macroscopical and microscopical features ${ }^{20,22,23,26)}$ have been published. In three $22,23,26)$ of these reports, histological features of transplanted tumors were compared to the original tumors, and only one $^{22)}$ of these showed biochemical characteristics in tumors in nude mice using immune serum against glial fibrillary acidic protein (GFAP). ${ }^{22)}$ In studies on heterotransplantation of human gliomas into athymic nude mice, the difficulty is mainly in developing a tumor in the mouse which shows histological features comparable with those of the original tumor. Morphological, biochemical and immunological studies have therefore been strictly limited. In addition, a large number of tumor cells was used to assure tumor-taking when compared with cell lines derived from tumors of other human organs. ${ }^{2,9,20,22,33)}$ Development of a new animal model for heterotransplantation of human tumors including gliomas, which until now failed to proliferate in athymic nude mice, has long been expected. 
Recently, a new mutant mouse strain with asplenia and athymia was introduced by Lozzio (lasat mouse). ${ }^{15,16,17)}$ The lasat mouse, which has no cellular and little humoral immunity, ${ }^{15,17)}$ may improves the transplantability of human tumors. We reported previously a heterotransplantation study on an established human glioma cell line into lasat mice in a short communication. ${ }^{34)}$ In this paper we describe further studies on heterotransplantation of a human glioma cell line into lasat mice, including morphological and biochemical characteristics compared with the original tumor.

\section{Materials and Methods}

\section{Cell line and its properties in vitro for heterotransplantation}

Cell line KNS-42 (Kyushu University Neurosurgery Tumor Cell Line Number 42) was originally established by Takaki $^{34)}$ from a glioblastoma located in the right posterior frontal and parietal lobes of a 16-year-old boy (NS 720440), and maintained in a tissue culture for more than five years. The cell line is not cloned. For maintenance and in vitro studies, Eagle's minimal essential medium (Nissui Seiyaku, Co., Tokyo, Japan) supplemented with $10 \%$ fetal bovine serum (FBS) (Microbiological Associates Inc., Bethesda, U.S.A.) and $300 \mathrm{mg} / 1$ of L-glutamine was used. The cell growth was monitored with an inverted phase contrast microscope. The cell population doubling time was determined in a logarithmic phase from the growth curve. To determine the plating efficiency, 100 and 200 cells were seeded in Falcon plastic petri dishes and incubated at $37^{\circ} \mathrm{C}$ under humidified conditions with $5 \% \mathrm{CO}_{2}$ in air. All assays were maintained for 14 days and stained with Giemsa solution. Visible colonies which contained five or more cells were counted directly. The saturation density was determined as described by Smith et al. ${ }^{281}$ Colony formation in agar medium was studied by the method of Machpherson et al., ${ }^{18)}$ and $0.33 \%$ agar containing 500 to 1,000 cells per dish was applied on the base layer of $0.55 \%$ agar using Falcon plastic petri dishes. For chromosome analysis, the cells were treated with Colchicin $(0.25 \mu \mathrm{g} / \mathrm{ml}) 48$ hours after subculture for 12 hours, pipetted, treated with
$0.075 \mathrm{M} \mathrm{KCl}$ hypotonic solution for $15 \mathrm{~min}$, fixed with methanol-glacial acetic acid $(1: 1)$, and stained with Giemsa solution.

\section{Heterotransplantation}

The hereditary asplenic-athymic (lasat) mice was bred under sterilized conditions with a laminar airflow barrier system as described previously. ${ }^{34)}$ For heterotransplantation, male or female young adult mice, 1 to 4 months old, were used. Four lasat mice were inoculated with $1 \times 10^{7}$ cells (passage 127 to 147 ) subcutaneously in the dorsal area and the other two were inoculated with $8 \times 10^{6}$ and $6 \times 10^{6}$ cells respectively. The mice were sacrificed after the inoculation periods ranging from one and a half months to 7 months, and the tumors in mice were subjected to morphological, biochemical and chromosomal studies.

\section{Histological studies}

The tumors developed in lasat mice were removed and fixed in $10 \%$ formalin for paraffin embedding and in $4 \%$ phosphate-buffered glutaraldehyde for epon embedding. Hematoxylin-eosin (HE), elastica van Gieson and phosphotungstic acid hematoxylin (PTAH) stainings were employed. One micron epon sections were cut and stained with toluidine blue to obtain the proper part for electron microscopy. Thin sections were cut with a diamond knife, stained with uranyl acetate and lead citrate, and observed under an electron microscope (Hitachi HS-9).

\section{Immunodiffusion studies}

The rabbit immune serum reactive specifically against GFAP G $^{1,8,11,21,32)}$ was kindly supplied by Dr. Bignami (Stanford University School of Medicine), and was employed for Ouchterlony double diffusion studies using $1.15 \%$ agar in phosphate-buffered saline (PBS) solution. The cultured cells and minced tumor tissue were treated with a Sonifier cell disruptor (Heat System-Ultrasonics, Ins., Plainview, N.Y.) with a small amount of PBS solution, and were centrifuged at $4,500 \mathrm{~g}$ for $30 \mathrm{~min}$. Bovine brain was homogenized in a Warring blender with PBS solution $(1: 3 \mathrm{w} / \mathrm{v})$ and centrifuged at $10,000 \mathrm{~g}$ for $30 \mathrm{~min}$. Adult mouse (BALB/c) brain was homogenized using a glass homogenizer with PBS solution (1:2w/v) 


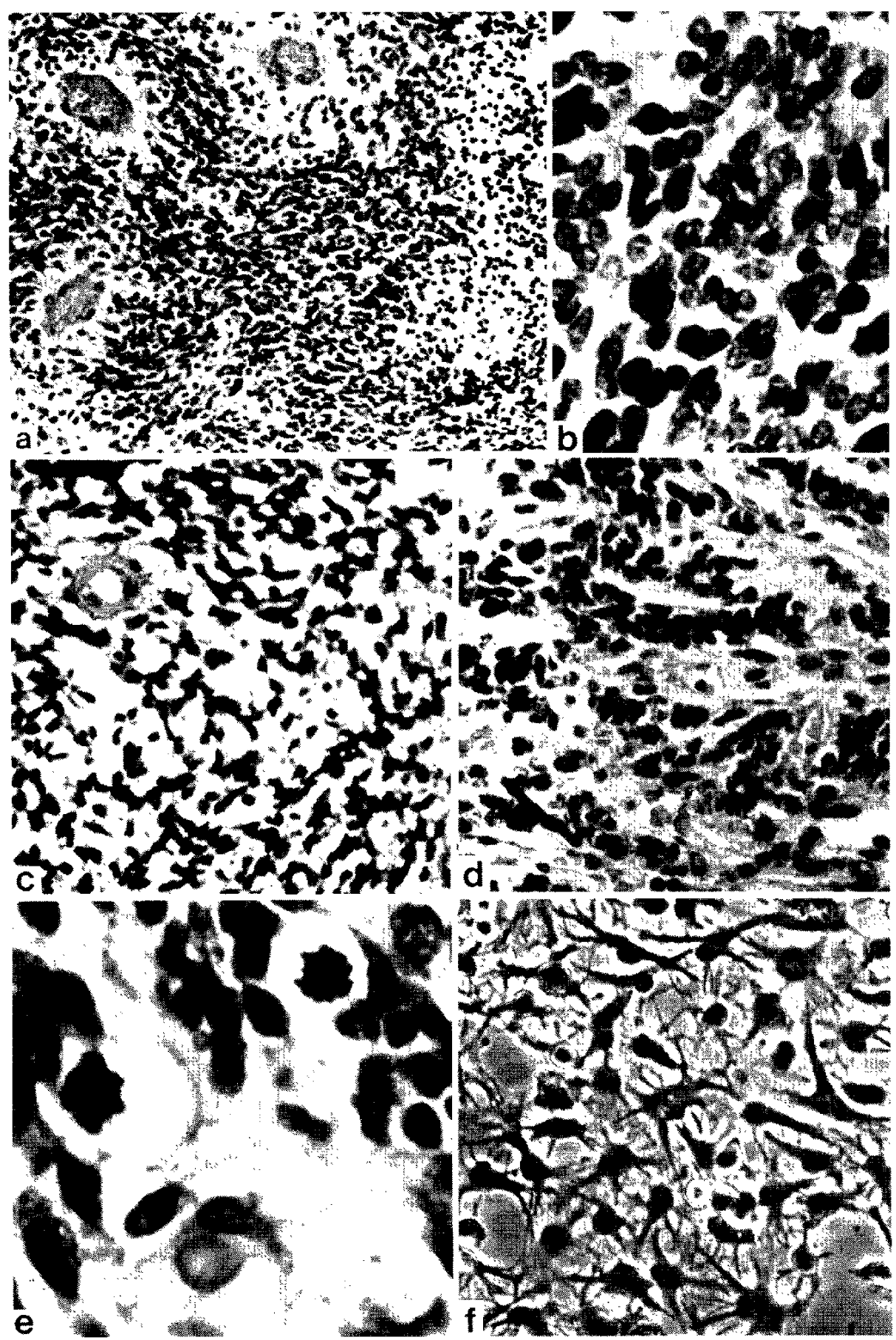

Fig. I Histological features of the original human glioblastoma (a-e, HE stain) and morphological features of the cell line KNS-42 (f, phase contrast). The perivascular arrangement of tumor cells, endothelial proliferation and small necrotic foci are shown $(a, \times 160)$. An anaplastic area $(b, \times 600)$, pilocytic area $(c, \times 300)$, palisading pattern $(\mathrm{d}, \times 300)$ and mitotic figures $(e, \times 1200)$ are also seen. Cell line KNS-42 (passage 142) 24 hours after subculture showing typical astrocytic configurations $(f, \times 240)$. 
and centrifuged at $10,000 \mathrm{~g}$ for $30 \mathrm{~min}$. The samples were allowed to diffuse for 18-24 hours at $4^{\circ} \mathrm{C}$ in a moist atmosphere box and were stained with amido black $10 \mathrm{~B}$ solution.

\section{Reculture of the tumor in lasat mice}

RPMI-1640 (Nissui) supplemented with 20\% FBS was used for reculture of the tumor grown in lasat mice. The minced tumor tissue was cultivated in Falcon culture bottles. At the outgrowth of tumor cells, chromosomes were studied as described above.

\section{Results}

\section{Histological features of the original tumor} Histologically the original tumor (Fig. 1a $\sim$ e) consisted of cells with small round or oval nuclei and scanty cytoplasm. The perikaryon was separated from the vessels in some areas, and the cell processes extended to the vessel wall, forming a halo of tangle fibers around the vessels (Fig. Ia). Small necrotic foci and endothelial proliferations were also noted. Anaplastic areas (Fig. Ib), pilocytic areas (Fig. 1c), palisading patterns (Fig. Id) and many mitotic figures (Fig. le) were also noted. No rosettes or blepharoplasts were identified. According to these findings the original tumor was diagnosed as a glioblastoma.

\section{In vitro properties of the cell line studied for heterotransplantation}

The morphological features of the cell line were

Table I In vitro propertics of the cell line for heterotransplantation

Cell morphology

Population doubling time (hours) $\quad 35$

polygonal, short and broad membranous processes with narrow and thick ridges

Saturation density (cell $/ \mathrm{cm}^{2}$ )

Plating efficiency on solid substrate

Colony formation in agar medium

Chromosome analysis considered as typically astrocytic. The cultured cells were polygonal and had several rather short and broad membranous cytoplasmic processes. In addition, there were more narrow and thicker ridges radiating from the nucleal region, occasionally ramified, a few days after subculturing (Fig. 1f). In chromosome studies 100 cells were counted, and two model numbers (66 and 74) were revealed (Fig. 7). The majority $(83 \%)$ of the cells were nearly triploid $(46 \%$ with 70-77 chromosomes and 37\% with 62-69) and $9 \%$ were hyperdiploid with 56-61 chromosomes. Other in vitro properties are shown in Table 1.

III. Histological features of the tumors developed in lasat mice

A. Paraffin section: The tumor was developed at the injected site in all lasat mice and harvested at various inoculation periods ranging from one and a half months to 7 months. In a lasat mouse inoculated with $1 \times 10^{7}$ cells, a small nodule was observed at the injected site during the first few weeks, and then it gradually grew to a size of $17 \times 17 \times 10$ $\mathrm{mm}$ in two and a half months after inoculation. ${ }^{34)}$ A lasat mouse five and a half months after inoculation with $8 \times 10^{6}$ cells is shown in Fig. 2. The tumors grown in lasat mice showed histological features (Fig. 3a, b) strikingly similar to those of the original tumor. They consisted of cells with small round or oval nuclei and scanty cytoplasm, but the nuclei were more hyperchromatic and the tissue was more cellular than the original tumor. Mitotic figures, small necrotic foci and endothelial proliferation were common. Small cysts were also occasionally noted near the center of the tumor. At the periphery of the tumor there were clusters of large tumor cells which stained dark blue in PTAH preparations. In some areas, tumor cells proliferated invasively beyond the lasat mouse proper connective tissue capsule.

B. Electron microscopic observations. Ultrastructurally small, round or oval cells had rather large nuclei, a moderate amount of chromatin content and less prominent nucleoli. The cytoplasm was rather scanty and had many polysomes, a few mitochondria and a rough endoplasmic reticulum. The cell boundary was rather simple and smooth plasma 


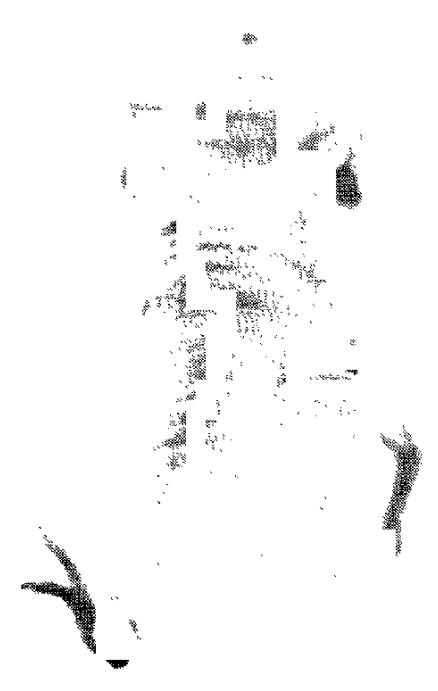

Fig. 2 A lasat mouse five and a half months after inoculation with $8 \times 10^{6} \mathrm{KNS}-42$ cells (passage 139). membranes were simply abutted without any special junctional complexes. In addition, larger, more cytoplasm-rich cells with abundant glial filaments were present (Fig. 4a). Their diameter was $9-10 \mathrm{~nm}$. Under high power microscopy, these filaments showed hollow centers (Fig, 4b). The details of these neoplastic cells will be described elsewhere. ${ }^{25}$ )

\section{Immunodiffusion study}

In Ouchterlony double diffusion studies of rabbit immune serum against GFAP, precipitation lines were observed with the extracts of the cultured cells, of the tumor developed in a lasat mouse and of bovine brain as well. No definite precipitation line was obtained with mouse brain (Fig. 5).

V. Chromosome study of re-cultured tumor cells Sixty-six cells were counted. The majority $(71 \%)$ of the cells were hypotriploid or hyperdiploid $(47 \%$ with $57-65$ chromosomes and 24\% with 50-56) (Fig. 7), and the representative

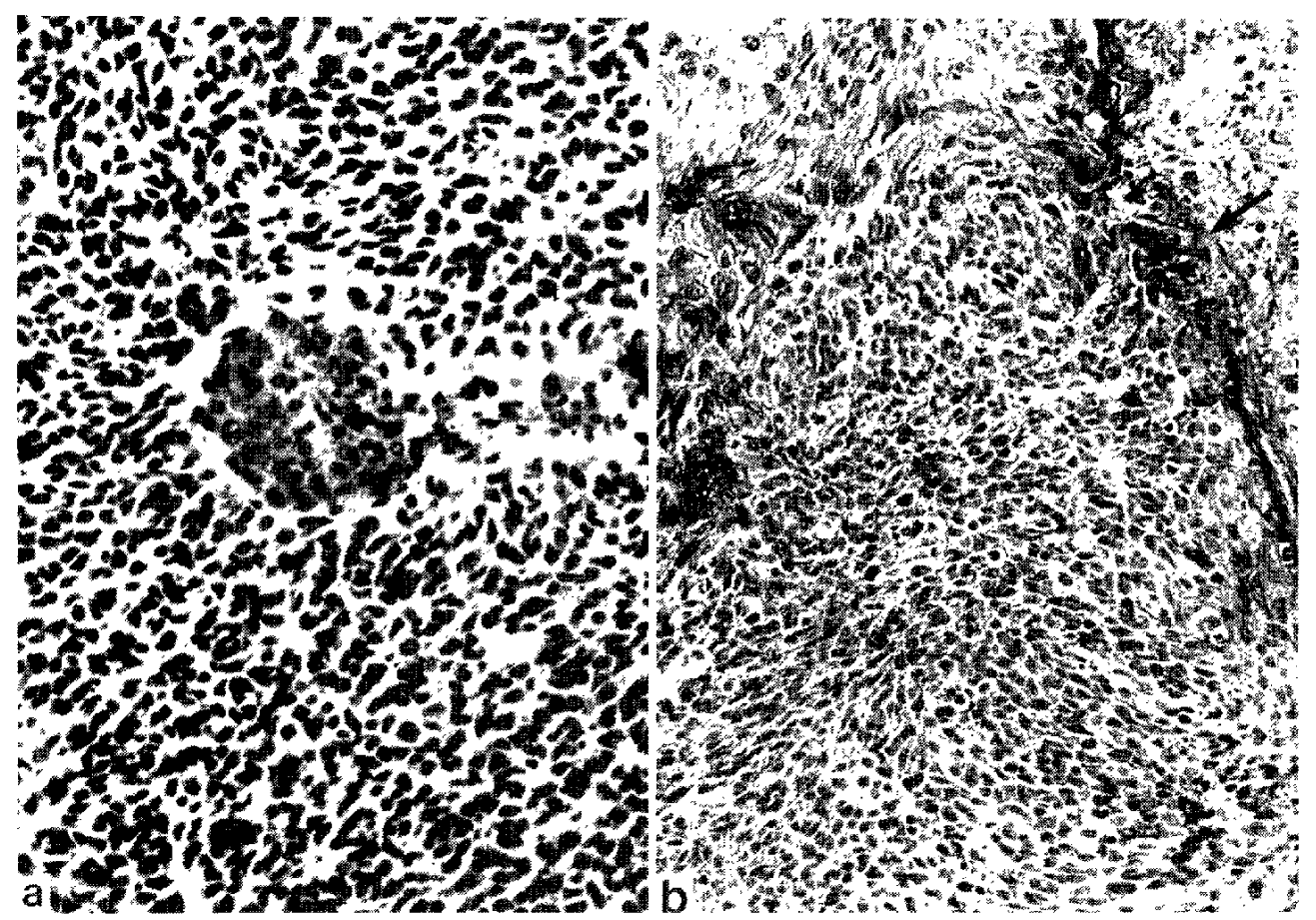

Fig. 3 Photomicrograph of the tumor developed in the lasat mouse seen in Fig. 2. The tumor tissue remote from the tumor capsule is composed of cells with small round or oval nuclei and scanty cytoplasm. Note high cell density, marked endothelial proliferations (a, HE stain. $\times 220$ ). At the periphery of the tumor there were clusters of large tumor cells and tumor cells emigrating outward (right) through the tumor capsule (arrow) enclosing the tumor (b, PTAH stain. $\times 160$ ). 


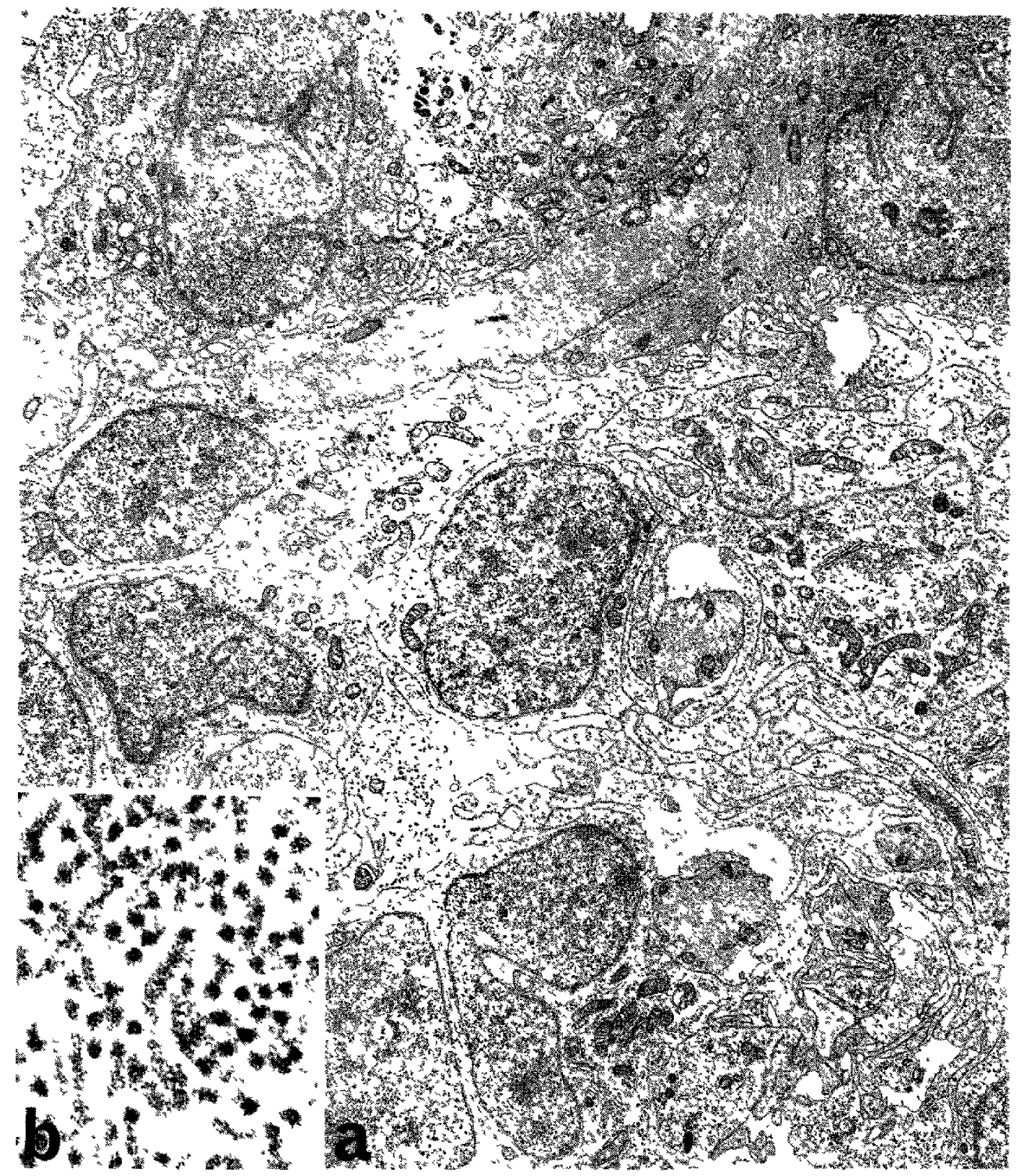

Fig, 4 Electron micrograph of the tumor in a lasat mouse The small cytoplasmpoor cells with apposing smooth plasma membrane The main organella were polysomes The nucleus was round and showed sparse chromatin Glial filaments were also seen in large cells $(\mathrm{a}, \times 5500)$ Under high power microscopy, the cytoplasmic filaments showed hollow centers $(b, \times 165000)$

karyotype in a model number 59 was revealed (Flg 6)

\section{Discussion}

In the studies of heterotransplantation of human glıoma cell lines, several species of anımals including hamsters, ${ }^{19,23)}$ guınea pigs ${ }^{19)}$ and athymic nude mice $\left.{ }^{2} 914,20,22,23,33,34\right)$ have been used in recent years In the previous studies on the athymic nude mouse, successful transplantation required $\left.3 \times 10^{7}, 2,33\right) 2 \times$ $\left.10^{7},{ }^{9,20.22)} 6 \times 10^{6}, 23\right)$ or $1 \times 10^{6}{ }^{23}$ ) human glioma cells The histological features of the tumors developed in nude mice were similar to the original ones in some cases, ${ }^{22,23)}$ and not in other cases ${ }^{20)}$ In these studies the tumors were harvested between 16 and 147 days 


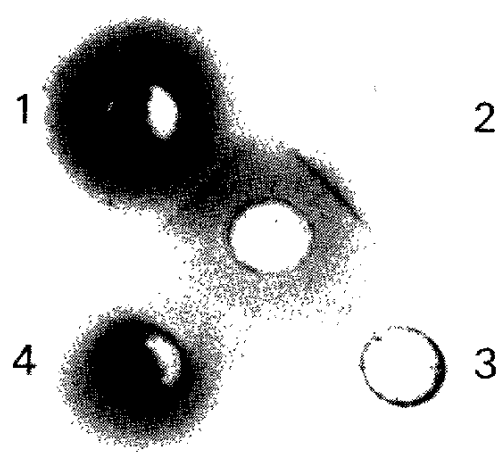

Fig. 5 Ouchterlony double diffusion of the rabbit immune serum against GFAP (in the center well) with the extracts of original cultured cells (1), bovine brain (2), tumor in lasat mouse (3) and mouse brain (4).

after inoculation. $2,9,20,22,23,33$ ) The chromosome study of the tumor developed in nude mouse was reported in only one paper which verified a human karyotype as the original cell line. $^{23)}$ Only Maunoury et al. ${ }^{22)}$ studied biochemical characteristics of the heterotransplanted tumor in nude mice by the immunoperoxidase method using immune serum anti-GFAP and confirmed its presence in these cells.

In the present study, six lasat mice were inoculated with $6 \times 10^{6}$ to $1 \times 10^{7}$ cells subcutaneously, and all developed tumors at the injected site, the largest being $17 \times 17 \times 10 \mathrm{~mm}$ in size. Histologically, the tumors were strikingly similar to the original ones. High cell density, perivascular arrangement of tumor cells, marked endothelial proliferation, abundant mitotic figures, and small necrotic foci were evident.

Among the studies on heterotransplantation of human glioma cell lines to the athymic nude mouse, there have been no comprehensive reports including light and electron microscopic observations, chromosomal analysis and biochemical studies on the presence of specific markers of GFAP. To develop tumors in lasat mice, a rather small number of cells were needed in our studies. Furthermore, neoplastic growths could be harvested at various inoculation periods ranging from one and a half months to 7 months, during which time the tumors in lasat mice grew progressively. The lasat mouse may be the first animal model in which a reliable tumor is produced for the study of heterotransplantation of human glioma cell lines. Our experiments should offer valuable evidence supporting Lozzio's suggestion that lasat mice improve the transplantability of human tumors. ${ }^{15}$ )

By using a mutant mouse with asplenia and athymia, it became clear that cell line KNS-42 derived from a human glioblastoma had tumorgenicity, and the fact that the tumors developed in lasat mice reproduced almost the same histological findings as the original human tumor may indicate that cell line KNS42 has long been maintained in good condition in the tissue culture. In addition, the tumor cells in lasat mice proliferated invasively beyond the connective tissue enclosing the
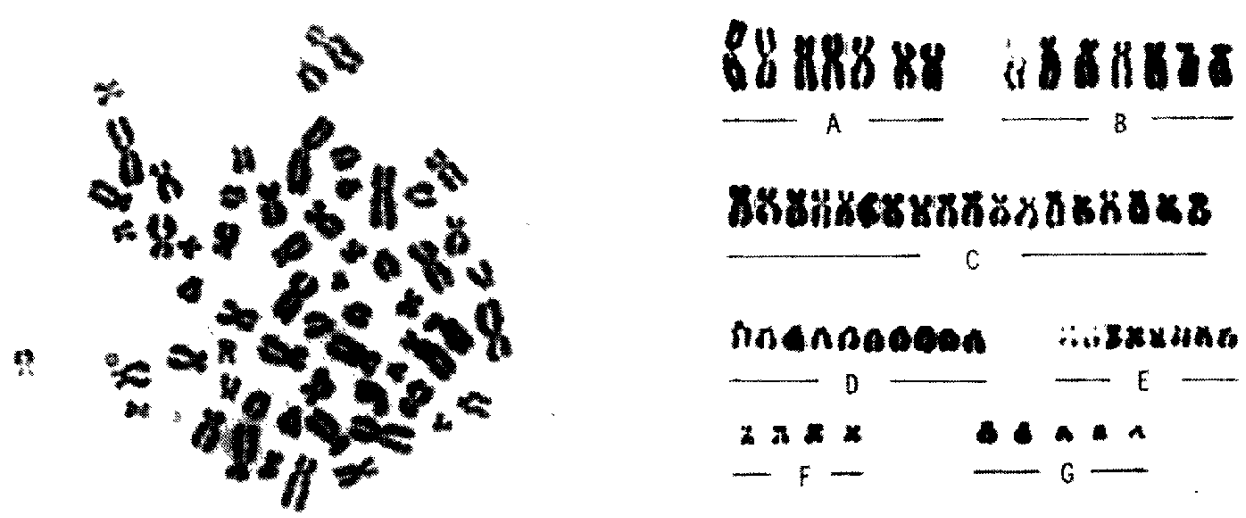

Fig. 6 Karyotype of the chromosomes from a re-cultured tumor cell with 59 chromosomes. 


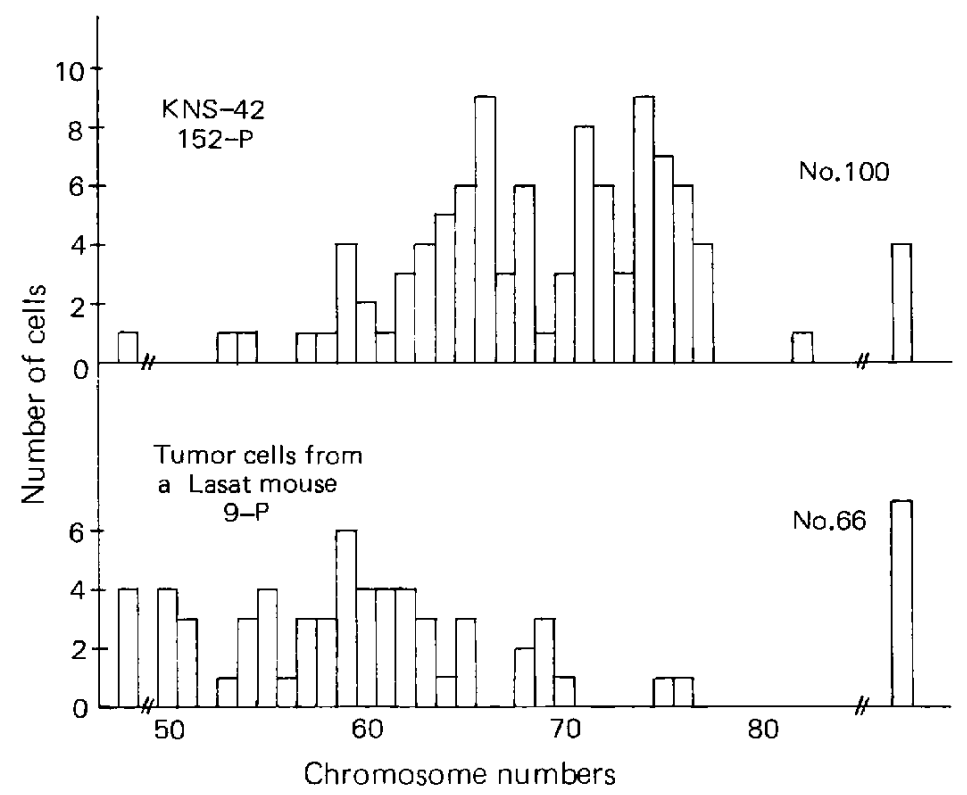

Fig. 7 Histogram showing marked alteration of the distribution of chromosome numbers between cell line KNS-42 and cells from a tumor developed in a lasat mouse. P-152 and P-9 indicate total passages in vitro of the cells, and No. 100 and No. 66 indicate the number of metaphase cells examined.

tumor. This indicates the high malignancy of cell line KNS-42.

From the findings of glial filaments demonstrated by electron microscopy and GFAP using the Ouchterlony double diffusion technique, the cell line should also be valuable for studies on ultrastructural localization of GFAP. Immunohistochemical aspects of these materials are being investigated.

The chromosomal rearrangements noted in comparisons of the original cell line $(46 \%$ with 70-77 chromosomes and $37 \%$ with 62-69) with the recultured tumor cells (47\% with $57-$ 65 and $24 \%$ with 50-56) may indicate a chromosomal selection ${ }^{16)}$ of KNS-42 cells in lasat mice. Tumor cells with selected numbers of chromosomes may develop tumors in lasat mice more rapidly. An alternate in vitro and in vivo passage method is now being investigated in this respect.

Remarkable endothelial proliferation in tumors in lasat mice as in the original tumor suggested that this cell line might be useful for the studies on tumor angiogenesis factors in central nervous system tumors. ${ }^{13)}$ In addition, it was suggested that the vascular structure in the tumor heterotransplanted into lasat mice can be prescribed by the tumor cell itself.

\section{References}

1) Bignami, A., Eng, L. F., Dahl, D. and Uyeda, C. T.: Localization of the glial fibrillary acidic protein in astrocytes by immunofluorescence. Brain Res 43: 429-435, 1972.

2) Bigner, D. D., Markesberry, W. R., Pegram, C. N., Westermark, B. and Pontén, J.: Progressive neoplastic growth in nude mice of cultured cell lines derived from human glioma. J Neuropathol Exp Neurol 36: 593, 1977.

3) Dahl, D. and Bignami, A.: Glial fibrillary acidic protein from normal human brain. Purification and properties. Brain Res 57: 343-360, 1973.

4) Dahl, D. and Bignami, A.: Immunochemical and immunofluorescence studies of the glial fibrillary acidic protein in vertebrates. Brain Res 61: 279-293, 1973.

5) Dahl, D. and Bignami, A.: Glial fibrillary acidic protein from normal and gliosed human brain. Biochim Biophys Acta 386: 41-51, 1975.

6) Deck, J. H. N., Eng, L. F., Big, J. and Woodcook, S. M.: The role of glial fibrillary acidic protein in the diagnosis of central nervous system tumors. Acta Neuropathol 42: 183-190, 1978.

7) Duffy, P. E., Graf, L. and Rapport, M. M.: Identification of glial fibrillary acidic protein by the immunoperoxidase method in human 
brain tumors. $J$ Neuropathol Exp Neurol 36: 645-652, 1977.

8) Eng, L. F., Vanderhaeghen, J. J., Bignami, A. and Gerstl, B.: An acidic protein isolated from fibrous astrocytes. Brain Res 28: 345350, 1971.

9) Fogh, J., Fogh, J. M. and Orfeo, T.: One hundred and twenty-seven cultured human tumor cell lines producing tumors in nude mice. J Natl Cancer Inst 59: 221-226, 1977.

10) Hirohashi, S., Shimosato, Y., Kameya, T., Koide, T., Mukojima, T. and Taguchi, Y.: Morphological and functional aspect of human liver cell carcinomas transplanted in nude mice. In Proceedings of the Second International Workshop on Nude Mice. Tokyo, University of Tokyo Press, 1977, pp 427-434.

11) Jacque, C. M., Vinner, C., Kujas, M., Raoul, M., Racadot, J. and Baumann, N. A.: Determination of glial fibrillary acidic protein (GFAP) in human brain tumors. $J$ Neurol Sci 35: 147-155, 1978.

12) Kameya, T., Shimosato, Y., Hayashi, H. and Tsumuraya, M.: Growth and differentiation of hormone-producing human tumor in nude mice. In Proceedings of the Second International Workshop on Nude Mice. Tokyo, University of Tokyo Press, 1977, pp 406-416.

13) Kelly, P. J., Suddith, R. L., Hutchison, H. T., Werrbach, K. and Haber, B.: Endothelial growth factor present in tissue culture of CNS tumors. $J$ Neurosurg 44: 342-346, 1976.

14) Kuga, N., Seido, T. and Oboshi, S.: Heterotransplantation of cultured human cancer cells and human cancer tissues to nude mice. Gann 66: 547-560, 1975.

15) Lozzio, B. B.: The Lasat mouse: A new model for transplantation of human tissues. Biomedicine 24: 144-147, 1976.

16) Lozzio, B. B., Machado, E. A., Lozzio, C. B. and Lair, S.: Hereditary asplenic-athymic mice: Transplantation of human myelogenous leukemic cells. $J$ Exp Med 143: 225-231, 1976.

17) Machado, E. A. and Lozzio, B. B.: Animal model of human disease. Am $J$ Pathol 85: 515-518, 1976.

18) Machpherson, I. and Montagnier, L.: Agar suspension culture for the selective assay of cells transformed by polyoma virus. Virology 23: 291-294, 1964.

19) Manuelidis, E. E.: Experiments with tissue culture and heterologous transplantation of tumors. Ann NY Acad Sci 159: 409-431, 1969.

20) Maunoury, R.: Establishment and charac- terization of 5 human cell lines derived from a series of 50 primary intracranial tumors. Acta Neuropathol 39: 33-41, 1977.

21) Maunoury, R., Delpech, A., Delpech, B., Vidard, M. N., Vedrenne, C., Constans, J. P., et Hillereau, J.: Localisation de la proteine gliofibrillaire (GFAP) per immunocytochimie dans les tumeurs cerebrales humaines. Neurochirurgie 23: 173-185, 1977.

22) Maunoury, R., Courdi, A., Vedrennen, C. and Constans, J. P.: Localisation immunocytochimique de la proteine gliofibrillaire dans les heterogreffes de cultures de gliomes humains. Neurochirurgie 24: 221-226, 1978.

23) McAllister, R. M., Isaccs, H., Rongey, R., Peer, M., Au, W., Soukup, S. W. and Gardner, M. B.: Establishment of a human medulloblastoma cell line. Int I Cancer 20: 206-212, 1977.

24) Miwa, M., Hirohashi, S., Shimosato, Y., Mukojima, T., Ohkura, H., Sakura, H., Kawachi, T, and Sugimura, T.: Coproduction of carcinoembryonic antigens and $\alpha$ protein in transplantable human colon cancer in nude mice. In Proceedings of the Second International Workshop on Nude Mice. Tokyo, University of Tokyo Press, 1977, pp 435-439.

25) Ohta, M. and Yamashita, M.: in preparation.

26) Rana, M. W., Pinkerton, H., Thornton, H. and Nagy, D.: Heterotransplantation of human glioblastoma multiforme and meningioma to nude mice. Proc Soc Exp Biol Med 155: 85-88, 1977.

27) Shin, S., Reid, L. C., Colburn, P. C., Kadish, A. S. and Fleischer, N.: Development of transplantable functional endocrine tumor lines to nude mice. In Proceedings of the Second International Workshop on Nude Mice. Tokyo, University of Tokyo Press, 1977, pp 375-393.

28) Smith, H. S., Owens, R. B., Hiller, A. J., Nelson-Rees, W. A. and Johnston, J. O.: The biology of human cells in tissue culture. 1. Characterization of cells derived from osteogenic sarcomas. Int $J$ Cancer 17: 219234, 1976.

29) Sordat, B., Tamaoki, N. and Povlson, C. O.: List of tumors transplanted to nude mice. In Proceedings of the Second International Workshop on Nude Mice. Tokyo, University of Tokyo Press, 1977, pp 587-595.

30) Tamaoki, N., Hata, T., Izumi, S., Ueyama, Y. and Toyama, K.: Systemic effects of human renal cell carcinoma on nude mice: polycythemia, anemia, hypervolemia, and 
hepatomegaly. In Proceedings of the Second International Workshop on Nude Mice. Tokyo, University of Tokyo Press, 1977, pp 417-426.

31) Ueyama, Y., Morita, K., Yokoyama, M., Kondo, Y., Tamaoki, N., Ohsawa, N. and Nomura, T.: Establishment and maintenance of human malignant tumors serially transplanted to nude mice. In Proceedings of the Second Workshop on Nude Mice. Tokyo, University of Tokyo Press, 1977, pp 365-374.
32) Uyeda, C. T., Eng. L. F. and Bignami, A.: Immunological study of the glial fibrillary acidic protein. Brain Res 37: 81-89, 1972.

33) Wikstrand, C. J., Mahaley, M. S. and Bigner, D. D.: Surface antigenic characteristics of human glial brain tumor cells. Cancer Res 37: 4267-4275, 1977.

34) Yamashita, M., Takeshita, I. and Kitamura, K. : Heterotransplantation of human glioma in hereditary asplenic-athymic mouse. Gann 69: 735-736, 1978. 